\title{
JOURNALISM AND PARTICIPATORY PRACTICES BLURRING OR REINFORCEMENT OF BOUNDARIES BETWEEN JOURNALISM AND AUDIENCES?
}

\author{
Jan-Hinrik Schmidt, Wiebke Loosen, \\ Nele Heise and Julius Reimer ${ }^{1}$
}

\section{Introduction}

By now, it seems to be almost common wisdom that networked digital media contribute to fundamental changes in society. Part of this diagnosis is the assertion that boundaries between different spheres (such as public and private; e.g. Lüders, 2008), between different modes of communication (such as 'mass' or individual communication; e.g. Castells, 2007) or between different roles (such as producer and user; e.g. Bruns, 2008) are shifting - or at least re-configured. These developments have been scrutinized and debated by scholars and practitioners under labels such as "participatory journalism" (Domingo et al., 2008; Singer et al., 2011), "citizen journalism" (Antony \& Thomas, 2010), "participatory news" (Deuze et al., 2007) or "network journalism" (Heinrich, 2011). While concepts and explanations may vary in particular nuances, they usually agree on the observation that we are witnessing new combinations of professional, participatory and technical intermediation (Neuberger, 2009): Professional journalism is complemented (and challenged) by new forms of participation via user-generated content and social filtering. All this happens within a

1 Jan-Hinrik Schmidt and Wiebke Loosen are Senior Researchers and Nele Heise and Julius Reimer are Junions Researchers at the Hans Bredow Institute.

Recherches en communication, $\mathrm{n}^{\circ} 39$ (2013). 
context where new technological intermediaries such as Google News or Facebook additionally select and structure information via software code (e.g. algorithms).

Various aspects of these changes have been well documented in the academic literature, showing that audience participation and social media are increasingly relevant for journalism and do affect newsroom workflows and professional routines as well as journalistic role-conceptions (e.g. Hermida \& Thurman, 2008; Mitchelstein \& Boczkowski, 2009; Williams et al., 2010; Singer et al., 2011). Not only do platforms like Facebook, Twitter or YouTube provide spaces for the emergence of "personal public spheres" (Schmidt, 2011) which complement journalistically produced public spheres. Online news sites also include spaces and mechanisms for user interaction, with one consequence being that journalists "who once controlled the space containing their work now share that space with website users" (Singer, 2010, p. 127).

Nevertheless, studies on participatory content on news sites (e.g. Rebillard \& Touboul, 2010; Jönsson \& Örnebring, 2011; Karlsson, 2011) as well as on journalistic expectations and self-images (e.g. Paulussen \& Ugille, 2008) provide evidence that journalists and news organizations do not react homogeneously to these developments, but strongly tend to defend their profession: "Every journalist acknowledges the current necessity of user participation. However, the way in which this is employed and viewed suggests that a 'minimalist' view of participation dominates in news organisations" (Witschge, 2011, p. 133).

Similar caution against naïve assumptions of a per-setransformativity of technological innovations is in order with respect to the audience. Not only is our theoretical understanding of the audience challenged (e.g. van Dijck, 2009; Carpentier, 2011), but there is also empirical evidence of a wide range and different extent of users' participatory practices (e.g. Boczkowski \& Mitchelstein, 2011). In addition, studies on users' attitudes and expectations have shown that there is some reluctance on the audience side to consider their own activities as journalistic practices (e.g. Fröhlich et al., 2012).

The traditional division between the scholarly fields of journalism research (focus on media production) and audience research (focus on media consumption) makes it even more difficult to adequately deal with these developments in a theoretical as well as methodological sense. This might explain why few studies yet combined both perspectives, on journalists and on (active) audience (Wardle \& Williams, 2010; 
Robinson, 2010). We need to further our understanding about the extent and the nuances to which the reconfiguration of the relationship between journalists and their audience leads to a blurring, a reconstruction or a reinforcement of the boundaries between them. ${ }^{1}$

Here, we present some work in progress on both the conceptual and the empirical aspects of these questions. After outlining a heuristic model that frames audience participation as inclusion and takes both journalists and audiences into account (chapter 2), we introduce the methodological design of a research project ${ }^{2}$ which consists of four case studies of German newsrooms, among them the leading public service newscast Tagesschau (chapter 3). The main part of the paper (chapter 4) presents findings on practices and expectations of the Tagesschau journalists towards audience participation, followed by a summary and outlook on further research (chapter 5).

\section{Analyzing audience participation: a heuristic model}

To assess the forms and consequences of audience participation in journalism, Loosen \& Schmidt (2012) have suggested an analytical framework (see figure 1) based on sociological inclusion theory. This framework makes two basic distinctions. The first derives from inclusion theory which posits that all social systems rely on performance roles and audience roles (Stichweh, 2005). ${ }^{3}$ Here, audience means that whenever a person benefits from or makes use of a social system's performance he or she becomes included into that system. Applied to the "social system journalism" (Görke \& Scholl, 2006), journalists act in the performance role and recipients in the audience role. Under mass media conditions, we face an inherent asymmetry between performance and audience role: While the former provides offers for public communication, the latter remains restricted to selective use of these communicative offerings. Hence, inclusion into the social system journalism under

1 As one notable exception, Lewis (2012) discusses three approaches, namely journalism as boundary work, as profession, and as ideology, which can be used as frames to assess shifts in the journalist-audience relationship.

2 The project is funded by the German Research Association (LO 853/4-1). The authors thank Christina Heller, Hendrik Holdmann, Mareike Scheler and Niklas Weith for their assistance.

3 E.g. in the political system we have politicians (performance role) and voters (audience role). 
mass media conditions is realized by merely accepting communication offers (Scholl, 2004).

With new means of audience participation it is assumed that this asymmetry is gradually changing into a more balanced relationship. To assess the extent of (a)symmetry, a second basic distinction is included in the model:

- Inclusion performance comprises practices which use mediating technologies to stimulate, articulate and aggregate communication between journalism and audience - interactions that might become directly manifest in journalistic output, but also takes place in publics 'outside' journalistic media (e.g. such blogs or social network sites), which nevertheless become part of journalism by referencing its output. Within journalism, these practices are part of professional routines and structures; among the recipients, these practices form networked audiences which exhibit different degrees of community orientation, e.g. practices of mutual observation and reciprocity.

- Inclusion expectations are framing the inclusion performance and are (re-)produced or changed through participatory practice. Within journalism, these expectations are part of professional selfimages, i.e. conceptions of the journalistic role as well as perceptions of the audience and its place and function within journalistic practices, but also criteria which guide strategic decisions of media organizations. Among the audience, expectations are mediated by motivations for participation and assessments of the impact these (individual and/or collective) contributions might have on journalism.

Altogether, the framework contains both basic distinctions, journalist/ performance roles vs. recipient/audience roles as well as inclusion performances vs. expectations. By contrasting the inclusion performances of journalism and audience we can assess the inclusion level, which can be high or low depending on the actual amount and scope of participatory practices; by contrasting inclusion expectations, we can assess the inclusion distance which can be large or small depending on the (in-)congruence of expectations. The model not only helps to systematize existing research (see Loosen \& Schmidt, 2012, p. 
874ff.), but might also serve as a heuristic for research designs. ${ }^{1}$ Since it allows for an assessment of participatory activities as well as processes of boundary work and demarcation, it can be used to identify areas of blurring boundaries or increased stability between journalism and audience.

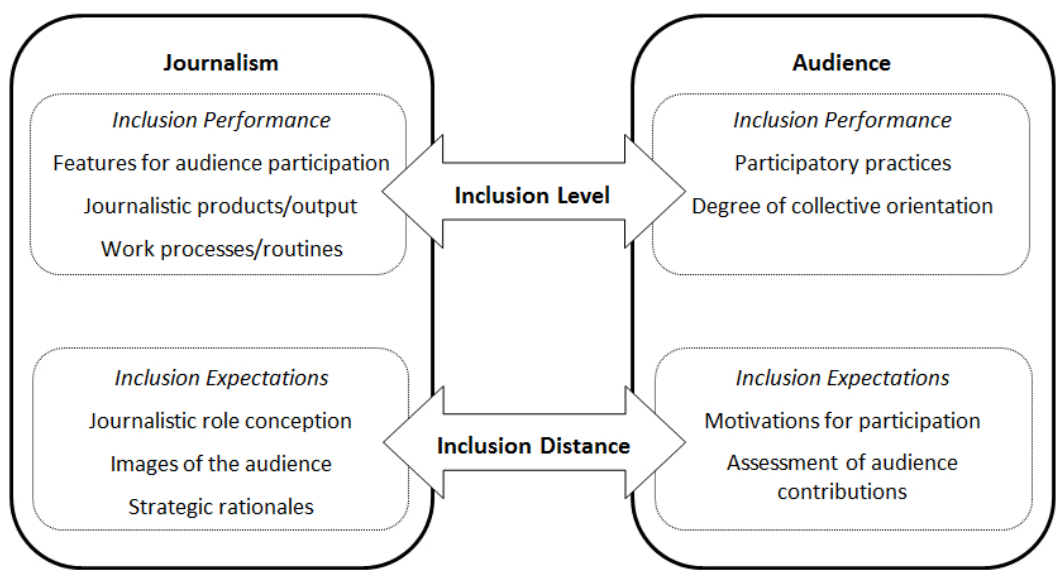

Figure 1. Analytical framework for audience inclusion in journalism Source: Loosen \& Schmidt, 2012, p. 874.

\section{Empirical Case: The Tagesschau}

The theoretical framework is currently being applied within the research project "(Re-) Discovering the Audience". ${ }^{2}$ Between 2011 and 2014, four case studies of different German newsrooms, from the convergence areas of TV-Online and Print-Online respectively, are conducted. The first case study on the Tagesschau was conducted between January and November 2012 and applied several empirical instruments, both quantitative and qualitative:

1 While this might suggest a precise quantified measurement, it is important to note that the model is also useful for qualitative analyses. In fact, our project combines various empirical instruments to gain comprehensive, multi-facetted insights on inclusion levels and distances.

2 For more information see: http://jpub20.hans-bredow-institut.de. 
(a) in-depth interviews with selected members of the editorial staff $(n=10)^{1}$ as well as

(b) in-depth interviews with viewers/users $(n=6)$;

(c) online surveys among the editorial department $(n=63)$ as well as

(d) standardized online surveys among the users of the online platform $(n=4.686)$; and

(e) content analysis of selected TV broadcasts as well as corresponding discussions on the tagesschau.de and on the Facebook fan page.

The Tagesschau ${ }^{2}$ is the main news broadcast of the ARD, the national network of the German regional public service broadcasters. It started in 1952 with three shows per week, thus being the oldest still running newscast. Today, up to 23 shows are broadcast per day, with the newscast at $8 \mathrm{pm}$ having the widest audience of about 10 million viewers or 33 per cent market share on average. ${ }^{3}$ Its editorial department is part of "ARD-aktuell", the central news department of the ARD network, where about 240 people (among them 100 reporters) work for the Tagesschau as well as for other news formats such as the Tagesthemen (a daily, late evening news magazine).

The online presence tagesschau.de was launched in 1996. Similarly to the TV newscast, the online department of about 20 journalists is part of "ARD-aktuell". Besides publishing videocasts of the TV shows, they also produce additional online content which is distributed on the website as well as on the mobile Tagesschau-App.

\section{Findings}

In the following sections, selected findings on the journalism side are presented: To assess journalistic inclusion performances, we discuss the practices of the social media editors (see 4.1). Inclusion expectations will be discussed with regard to findings on the selfimages of Tagesschau journalists (see 4.2).

1 The sample included different journalistic roles: chief editor [CE], leading editor online [LEO], 2 managing editors TV [METV], 2 managing editors online [MEO], 2 social media editors [SME], 2 multimedia assistants [MMA].

2 Here, Tagesschau refers to the whole news organization. Separate qualifiers are used to refer to the TV department or to the online department of tagesschau.de.

3 See http://intern.tagesschau.de/flash/index.php. These numbers include all Tagesschau viewers, i.e. the audience of ARD as well as regional and subsidiary channels, on which it is broadcast simultaneously. 


\subsection{Journalistic inclusion performance}

As part of its online strategy, the Tagesschau provides various participatory and social media elements, among them comment areas, an editorial blog and different external social media channels. In addition, a content center was introduced to monitor relevant sources, debates and content in social media.

\subsubsection{Using social media}

The current setup for user participation on tagesschau.de was introduced in 2009, when the former online forum was replaced by a new content management system. It allows registered users to comment and rate news items on tagesschau.de (about eight to twelve each day). Technically, user comments are collected and displayed on the subdomain meta.tagesschau.de, which has a different layout and provides specific navigational elements such as a tag cloud (tags are provided by tagesschau.de editors) and rankings of user-rated articles. This results in a clear distinction between journalistic content and the discussion area, which one of the online editors attributes to strategic rationales: "that was the right decision [...] because much is in there on which we do not want to stick the label Tagesschau" [MEO2]. Still, providing a space for discussion is seen as part of the public service mission of the Tagesschau, and the underlying idea of democratic participation and opinion formation [LEO].

Since 2007, the Tagesschau provides an editorial blog where leading editors and foreign correspondents publish postings which can be commented on by users. While the blog was used very enthusiastically at first [MEO2], today about two or three postings are blogged per week. They range from perspectives on topical news events or personal views by foreign correspondents to postings about internal editorial processes or decisions. Accordingly, the blog serves as an additional channel to foster user participation and conversation, but is also used to make the otherwise anonymous editorial staff somewhat visible to the audience. As an unintended side effect, some blog postings even stimulate internal discussion within the newsroom, e.g. about certain professional standards [LEO].

In addition to these participatory elements on tagesschau.de the Tagesschau hosts several external social media channels, e.g. a Facebook page (since 2010), and a profile on Google+ (introduced in 2012). 
Both pages are administrated by social media editors (see below) who publish five to ten postings per day, mainly referring to news stories on tagesschau.de. Two official Twitter-accounts - @ tagesschau (created in May 2007) and @tagesschau_eil (created in February 2009) - are automatically fed with news stories and breaking news; both accounts link back to the homepage. The YouTube-channel, which started already in August 2006, contains daily videocasts of the 8 pm newscast as well as of the extended late evening edition (Tagesthemen).

These social media channels provide not only additional outlets for the journalistic content but also spaces for feedback and input from the audience. To guarantee ongoing maintenance of these channels, two particular roles have been introduced at the Tagesschau. Multimedia Assistants, most of whom are students, work on a variety of tasks, e.g. updating the video content on the tagesschau.de. One of their rotating shifts also concerns the moderation of user feedback (see below).

Social media editors are responsible for the management of the social media channels, posting new articles or videos and responding to user questions, as well as for the so called content center. It was introduced in April 2011 as a new unit to organize the investigation and verification of information and audio-visual material for topics which have been discussed in the editorial conferences or have been identified as emerging stories on social media platforms. This material is sent to the managing TV and online editors who have the final say in the content selection and publication. Per day, two social media editors (out of ten, who also work for other editorial departments) work in two overlapping shifts on the social media profiles and investigation.

\subsubsection{Managing user participation}

Various routines have been established at the Tagesschan to structure and moderate user discussions on the different platforms. On the internal channels meta.tagesschau.de and the editorial blog, each comment has to be approved by the multimedia assistant working on that particular shift (principle of pre-moderation). Although every news article can only be commented for eight hours after publication, the volume of user participation is very high and approaches about 1.000 comments a day [MMA2]. The moderation decisions are based on a set of guidelines such as the prohibition of racist or pornographic content, and the reminder to engage in a constructive and friendly way. Articles on controversial topics (e.g. Middle East politics, right-wing 
extremism) cannot be commented at all, because these discussions escalated quickly in the past.

Based on these guidelines, about two thirds of the comments can be approved easily, while the remaining third is rejected or, in cases of doubt, discussed with the other multimedia assistants, taken to social media editors, or even to the head of the online department. When user discussions appear to get out of hand, or to drift off-topic, the moderators will interfere and remind users of the site's guidelines. In case of repeated or extreme violation of the guidelines, users can be banned from participation [MMA2].

As external channel, the Facebook page is not subject to the strict pre-moderation processes. However, there is still post-moderation to delete spam and extreme comments, and in some cases to remind users of the Tagesschau netiquette. Additionally, the social media editors observe forms of community regulation on Facebook, where other users call upon communication norms and rules to sanction comments which transgress these norms.

Comments on postings in the editorial blog often focus on journalistic procedures and standards and might be fed back to the editorial departments. In a few cases, the blog postings spark a conversation between journalists and the audience; some foreign correspondents, for instance, use the blog to get in touch with the users. But in most cases, and similar to meta.tagesschau.de as and the Facebook page, the blog comment section is a space where users discuss among themselves. While the assessment of user discussion on these spaces varies in some nuances, generally the tonality and quality of debates is considered to be better on the internal sites. Especially meta.tagesschau.de is described as an "opinion pool" with "pointed discussions" [LEO] that are more focused and content-oriented than on Facebook [SME1]. Partly, this is attributed to the on-going participation management on the site which has, from the journalists' perspective, resulted in a dedicated community.

\subsubsection{Learning about the audience}

By conceptualizing digital networked media, and social media in particular, as new spaces of inclusion performance, we have not only seen examples of new professional roles (social media editors) and editorial routines (managing user participation) but also differences in the resulting communication dynamics. Drawing these two strands 
together and adding some more insight from the survey, we can analyze one of the consequences of journalistic inclusion performance: It provides situations where journalists learn about their audience, which also contributes to their images of the audience (i.e. inclusion expectations; see chapter 4.2).

Asked about the main sources of information about their audience, most respondents picked letters or E-Mails, a rather classical feedback channel. Among respondents who work mainly for the TV newscast, personal encounters, TV ratings and results from market and media research are mentioned significantly more often. Respondents working for the online platforms, in contrast, do mention significantly more often access statistics and web analytics (i.e. new forms of aggregated feedback), but also the comments on tagesschau.de as means of getting information about their users. Additionally (and backed by the interviews), especially the social media editors and multimedia assistants act both as filters and multipliers for audience contribution among their colleagues, as they have rather direct access to audience feedback and user-generated material. So it is a combination of (direct) feedback from users, be it through interpersonal encounters, aggregated measures or the observation of user discussions, and indirect learning through the exchange with journalistic peers that provides information about the audience.

\subsection{Journalistic inclusion expectations: images of self and the audience at Tagesschau}

\subsubsection{Professional self-image}

The professional self-perception of the Tagesschau journalists is strongly framed by the image of this format as flagship of public service news journalism in Germany which provided reliable and objective quality news to generations of viewers. Or as the chief editor puts it: "the most valuable aspect for the Tagesschau is the trust people have in us" [CE]. This self-image is also framing internal negotiations about the extent and organization of audience inclusion at the Tagesschau. In particular, our informants described limits of audience orientation and participation by resorting to the journalistic core of the Tagesschau. To counter rising complexity in a world of information abundance, they argue that assessing the relevance of information and addressing topics should remain at the editor's discretion: "In the end we have 
to decide, based on our journalistic instinct [...], what the right offer is. [...] the journalists' task is not becoming less important, but even more important. We are those who have to disentangle the thousands and thousands of threads" [CE].

In addition to this predominant self-image of Tagesschau journalists, some informants articulated other role conceptions. One managing TV editor, for instance, pointed to the aspect of "explaining information". Here, he senses a shift: "It used to have sort of a missionary sense: 'We give information to you, and you have to deal with it'. Now it is more like: 'We give information to you and it is most important for us that you understand them"' [METV1]. Another journalist adds that he wants to "create publicity and transparency" [METV2].

While our informants from the online department share this general role perception of the Tagesschau and its journalists - especially the social media editors emphasize their strict quality standards regarding journalistic investigation and verification of online material - they largely reject traditional gatekeeper roles. Instead, they refer to different aspects and work routines, such as the exchange with the audience, and the management and filtering of user contributions. Overall, their professional role might be described as mediators between the TV and online departments as well as between journalists and active audience members.

However, the survey results indicate only small differences in the professional self-image between TV and online journalists (see table 1), with the only exception being the item "to control politics, business and society" (to which the TV journalists agreed significantly higher). Three items which were almost fully agreed on by all respondents point to a rather traditional understanding of professional news journalism: fast and objective delivery of precise information and explanation of complex issues. In contrast, possible journalistic tasks such as giving users the opportunity to publish their own content or to maintain social relations among each other are largely disregarded. In line with their diagnosed traditional idea of news journalism is that Tagesschau journalists rather agree to provide topics for discussion among the audience than to stimulate, moderate and engage in conversations themselves. The new means for interaction do apparently not result in a general conversational attitude of journalists. 


\begin{tabular}{|c|c|c|c|c|c|c|}
\hline \multirow[t]{2}{*}{$\mathrm{n}=63$} & \multicolumn{2}{|c|}{$\begin{array}{l}\text { TV } \\
(\mathrm{n}=34)\end{array} \quad$ staff } & \multicolumn{2}{|c|}{$\begin{array}{l}\text { Online } \quad \text { staff } \\
(\mathrm{n}=28)\end{array}$} & \multicolumn{2}{|l|}{ Total } \\
\hline & Mean & $\begin{array}{l}\text { S t d } \\
\text { Dev. }\end{array}$ & Mean & $\begin{array}{l}\text { S t d } \\
\text { Dev. }\end{array}$ & Mean & $\begin{array}{l}\text { S t d } \\
\text { Dev. }\end{array}$ \\
\hline $\begin{array}{l}\text { To explain and convey } \\
\text { complex issues }\end{array}$ & 4,94 & ,242 & 4,75 & ,645 & 4,85 & ,477 \\
\hline $\begin{array}{l}\text { To inform the audience as } \\
\text { objective and precise as } \\
\text { possible }\end{array}$ & 4,81 &, 749 & 4,73 &, 452 & 4,77 & 627 \\
\hline $\begin{array}{l}\text { To inform the audience as } \\
\text { fast as possible }\end{array}$ & 4,76 &, 561 & 4,67 & ,620 & 4,72 &, 585 \\
\hline $\begin{array}{l}\text { To point the audience to } \\
\text { interesting topics and show } \\
\text { them where to get further } \\
\text { information }\end{array}$ & 3,88 & 1,023 & 4,07 & ,900 & 3,97 & ,966 \\
\hline $\begin{array}{l}\text { To criticize problems and } \\
\text { grievances }\end{array}$ & 3,97 & ,984 & 3,74 & 1,095 & 3,87 & 1,033 \\
\hline $\begin{array}{l}\text { To concentrate on news that } \\
\text { is interesting to an audience } \\
\text { as wide as possible }\end{array}$ & 3,52 & 1,093 & 3,79 & 1,166 & 3,64 & 1,126 \\
\hline $\begin{array}{l}\text { To show new trends and } \\
\text { highlight new ideas }\end{array}$ & 3,27 & 1,206 & 3,52 & ,829 & 3,39 & 1,046 \\
\hline $\begin{array}{l}\text { To give the audience topics } \\
\text { to talk about }\end{array}$ & 3,27 & 1,180 & 3,45 & 1,183 & 3,35 & 1,175 \\
\hline $\begin{array}{l}\text { To control politics, business } \\
\text { and society } * *\end{array}$ & 3,44 & 1,418 & 2,28 & 1,306 & 2,90 & 1,478 \\
\hline To share positive ideals & 2,67 & 1,242 & 2,72 & 1,162 & 2,69 & 1,195 \\
\hline $\begin{array}{l}\text { To encourage and to } \\
\text { moderate discussion among } \\
\text { the audience }\end{array}$ & 2,88 & 1,212 & 2,48 & 1,479 & 2,69 & 1,348 \\
\hline $\begin{array}{l}\text { To provide useful } \\
\text { information for the audience } \\
\text { and act as advisor / guidance }\end{array}$ & 2,84 & 1,098 & 2,52 & 1,214 & 2,68 & 1,157 \\
\hline $\begin{array}{l}\text { To give people the } \\
\text { opportunity to express their } \\
\text { opinion about topics of } \\
\text { public interest }\end{array}$ & 2,61 & 1,116 & 2,48 & 1,214 & 2,55 & 1,156 \\
\hline $\begin{array}{l}\text { To build and maintain a } \\
\text { relationship to my audience }\end{array}$ & 2,61 & 1,022 & 2,24 & ,786 & 2,43 & ,927 \\
\hline
\end{tabular}




\begin{tabular}{|l|ll|ll|ll|l|}
\hline $\begin{array}{l}\text { To get into a conversation } \\
\text { about current events with } \\
\text { the citizens }\end{array}$ & 2,40 & 1,133 & 2,31 &, 850 & 2,36 &, 996 \\
\hline $\begin{array}{l}\text { To provide the audience } \\
\text { with entertainment and } \\
\text { relaxation }\end{array}$ & $1,90,908$ & 2,14 &, 875 & 2,02 &, 892 \\
\hline $\begin{array}{l}\text { To present my own ideas to } \\
\text { the audience }\end{array}$ & $1,63 \quad, 707$ & 2,04 &, 999 & 1,82 &, 873 \\
\hline $\begin{array}{l}\text { To provide people with the } \\
\text { opportunity to publish their } \\
\text { own content }\end{array}$ & $1,56 \quad, 619$ & 1,83 &, 848 & 1,69 &, 743 \\
\hline $\begin{array}{l}\text { To provide people with the } \\
\text { opportunity to maintain } \\
\text { social ties among themselves }\end{array}$ & 1,59 &, 979 & 1,55 &, 870 & 1,57 &, 921 \\
\hline
\end{tabular}

Table 1. Professional self-image

Note: "What are your personal goals in your profession?"; 5-point-Likert-scale with $1=$ "Do not agree at all" to $5=$ "Do agree completely" and $6=$ "Don't know / Can't say" (excluded for calculation of mean). Marked mean differences are significant with $* \mathrm{p}<.05, * * \mathrm{p}<.01, * * * \mathrm{p}<.001$ (ANOVA).

\subsubsection{Assessing the audiences ' motivations and contributions}

Complementary to their professional self-image, the Tagesschau journalists also have assumptions about their audience. As discussed in part 4.1.3, these are (partly) formed by information which is gathered through a variety of sources, which can be individualistic-specific (e.g. individual e-mails) or collective-aggregated (e.g. ratings) to various degrees. In addition to these images of the audience, our informants provided various recurring explanations and assumptions why users participate at the Tagesschau:

- For one, the assumption that users participate to express themselves and out of need for recognition is very prominent. This is repeatedly connected with the prestige of the Tagesschau, since some informants assume for example that users might "consider it an honor" [SME2] to see their name on tagesschau.de.

- A second assumed motivation is that of venting anger or frustration. Especially those informants who are involved in the 
daily management of user comments and confronted with the unfiltered feedback mention this.

- On the other hand, our informants also acknowledge that many users participate to give constructive feedback, which is very welcome, especially when it is useful for the news production process (e.g. reporting of errors).

The survey results on assumed user motivations back these findings and additionally indicate similarities but also some significant differences between TV and online editors (see table 2). On the one hand, online editors agree more to aspects like the public stating of opinions, the venting function of comments, and the self-expression and selfdisplay as driving motivations of active users. On the other hand, they disagree significantly stronger to the assumption that users participate in order to assist the journalists or to fulfill a civic obligation. This indicates that among online journalists a more individualistic image of users and their motivations is prevalent than among TV editors.

\begin{tabular}{|c|c|c|c|c|c|c|}
\hline \multirow[t]{2}{*}{$n=62-63$} & \multicolumn{2}{|l|}{ TV } & \multicolumn{2}{|c|}{ Online } & \multicolumn{2}{|l|}{ Total } \\
\hline & Mean & $\begin{array}{l}\text { St d } \\
\text { Dev. }\end{array}$ & Mean & $\begin{array}{l}\text { S t d } \\
\text { Dev. }\end{array}$ & Mean & $\begin{array}{l}\text { S t d } \\
\text { Dev. }\end{array}$ \\
\hline $\begin{array}{l}\text { To state their opinion } \\
\text { publicly } *\end{array}$ & 4,00 & ,696 & 4,41 & ,733 & 4,19 & ,737 \\
\hline $\begin{array}{l}\text { To vent anger and frustration } \\
*\end{array}$ & 3,71 & ,871 & 4,21 & 675 & 3,94 & ,821 \\
\hline $\begin{array}{l}\text { To point out errors in news } \\
\text { stories }\end{array}$ & 3,82 & ,808 & 3,76 & 912 & 3,79 & ,852 \\
\hline $\begin{array}{l}\text { For self-expression and self- } \\
\text { display } *\end{array}$ & 3,53 & ,788 & 3,96 & ,744 & 3,73 & ,793 \\
\hline $\begin{array}{l}\text { To share their knowledge } \\
\text { and experiences }\end{array}$ & 3,62 & ,888 & 3,70 & 912 & 3,66 & ,892 \\
\hline $\begin{array}{l}\text { To leave the passive viewer's } \\
\text { role }\end{array}$ & 3,44 & ,786 & 3,79 & ,787 & 3,60 & ,799 \\
\hline $\begin{array}{l}\text { To support and advocate a } \\
\text { certain concern, event or } \\
\text { group }\end{array}$ & 3,45 &, 754 & 3,52 & ,829 & 3,48 & ,784 \\
\hline $\begin{array}{l}\text { To propose a topic that is } \\
\text { important to them }\end{array}$ & 3,32 & ,768 & 3,54 & ,838 & 3,42 & ,801 \\
\hline
\end{tabular}




\begin{tabular}{|l|ll|ll|ll|}
\hline $\begin{array}{l}\text { To feel included in a } \\
\text { community }\end{array}$ & 2,90 & 1,106 & 3,11 & 1,086 & 3,00 & 1,092 \\
\hline Out of boredom & 2,48 &, 972 & 2,89 &, 801 & 2,67 &, 914 \\
\hline $\begin{array}{l}\text { To expand their own } \\
\text { knowledge by interacting } \\
\text { with journalists and other } \\
\text { viewers/users }\end{array}$ & 2,58 &, 792 & 2,39 &, 685 & 2,49 &, 744 \\
\hline $\begin{array}{l}\text { To build a relationship with } \\
\text { the editors }\end{array}$ & 2,44 &, 878 & 2,32 &, 819 & 2,38 &, 846 \\
\hline $\begin{array}{l}\text { To assist the journalists in } \\
\text { their work * }\end{array}$ & 2,56 &, 746 & 2,10 &, 860 & 2,35 &, 826 \\
\hline To find help with a problem & 2,33 &, 777 & 2,31 &, 891 & 2,32 &, 825 \\
\hline $\begin{array}{l}\text { To fulfill their civic } \\
\text { obligations * }\end{array}$ & 2,48 &, 712 & 2,07 &, 799 & 2,29 &, 776 \\
\hline
\end{tabular}

Table 2. Assumed participation motivations, by TV and Online editors

Note: "What do you think are the reasons that people participate in Tagesschau/ tagesschau.de?"; 5-point-Likert-scale with $1=$ "Does not apply at all" to $5=$ "Does fully apply" and 6 = "Don't know / Can't say" (excluded for calculation of mean). Marked mean differences are significant with $* \mathrm{p}<.05, * * \mathrm{p}<.01, * * * \mathrm{p}<.001$ (ANOVA).

\section{Conclusion}

From a theoretical perspective, we have considered participation as a particular element of audience inclusion in journalism, which comprises of inclusion performances and expectations. By discussing selected findings from a case study on a leading German TV newscast, the Tagesschau, we have also seen that both elements depend on each other. On the one hand, inclusion performance is both framed by and framing inclusion expectations: how journalists see their own professional role, and how they imagine their audiences' motivations, is influencing the amount, range and assessment of participatory options in their daily work routines. On the other hand, recurring encounters with the audience, through direct interaction or various forms of (filtered or aggregated) feedback influence the professional self-image and the image of the audience, in terms of an assessment of particular audience contributions and of its general place in the news production process.

Regarding inclusion expectations, the perception of the Tagesschau as a trusted journalistic brand strongly affects not only the role conceptions of journalists but also their attitudes towards audience 
participation. Hence, the image of the Tagesschau as a credible, reliable and highly regarded newscast serves as lens through which different facets of inclusion performances are assessed and decided upon. This backs Heinonen's (2011, p. 53) conclusion "that how journalists see themselves shapes how they see users, as well as how they see the relationships between those inside and outside the newsroom". In this context, our informants agree on the necessity and general value of providing spaces for user discussions and conversations, but at the same time they reject direct audience influence in the journalistic content. While several nuances do exist - e.g. different assessments of the ratio between constructive and pointless user feedback on journalistic work, or different reliance on social media sources for additional information in daily reporting -, they do not blur the basic premise of the Tagesschau as news medium produced by professional journalists.

The case study also reveals a tension connected to the costs of audience inclusion. Managing the different feedback spaces and running the content center is time-consuming, and the necessary editors and assistants cannot easily be added on top of existing personnel. While the modification of work routines, e.g. the rotation of regular TV and online editors into the social media department, helps to adapt, there might arise a conflict between the ever-increasing demands of audience participation and the core operations of the Tagesschau newscast. These limiting factors for the integration of audience contributions, such as a lack of time and money and high work pressure, are very much in line with previous empirical findings (e.g. Paulussen \& Ugille, 2008). Indeed, audience participation seems to be more a problem to manage rather than a benefit for the news product, as Domingo (2008) puts it.

A second tension is becoming visible through audience participation, namely between "creative and quantified audiences" (Anderson, 2011). While under mass media conditions journalists work(ed) mainly with an "operative fiction" (Zurstiege, 2006, p. 65) of their audience, new inclusion practices seem to challenge this. The audience has become more visible for journalists, both in terms of aggregated (monitoring and audience measurement) and singular feedback (contributions of individual users). Accordingly, the Tagesschau journalists develop multifaceted images of their audience that differ depending on the editorial roles and extent of daily interaction with the audience. A common trope in the interviews pointed to the idea of the dual audience: one (smaller) part of the audience being visible through their active participation - an image that also includes different types of active users based on their 
assumed intentions or communicative behavior -, and a much larger part of the audience merely consuming the journalistic output. As a result, journalists seem to have more nuanced images of their audience due to a broad range of information sources, but nevertheless still rely on operative fictions of their audience.

Regarding the starting question about blurring or reinforcement of boundaries, our case study finds evidence for both. While certain aspects of news journalism are opened for increased inclusion of the audience, journalistic standards and professional routines are defended and reinforced. Thus, the growing demands for (audience) participation stimulate not only journalistic self-reflection about their professional identity, but are also situated in larger societal discourses about the transformation of public spheres and democracy.

\section{Références}

Anderson, C. W. (2011). Between Creative and Quantified Audiences: Web Metrics and Changing Patterns of Newswork in Local US Newsrooms. Journalism, 12(5), $550-566$.

Antony, M. G., \& Thomas, R. J. (2010). 'This is Citizen Journalism at its Finest': YouTube and the Public Sphere in the Oscar Grant Shooting Incident. New Media and Society, 12(8), 1280-1296.

Boczkowski, P. J., \& Mitchelstein, E. (2011). How Users Take Advantage of Different Forms of Interactivity on Online News Sites: Clicking, E-Mailing, and Commenting. Human Communication Research, 38(1).

Bruns, A. (2008). Blogs, Wikipedia, Second Life, and Beyond: From Production to Produsage. New York: Peter Lang.

Carpentier, N. (2011). New Configuration of the Audience?: The Challenge of UserGenerated Content for Audience Theory and Media Participation. In V. Nightingale (Ed.), The Handbook of Media Audiences (pp. 190-212). Chichester: WileyBlackwell.

Castells, M. (2007). Communication, Power and Counter-Power in the Network Society. International Journal of Communication, 1(1), 238-266.

Deuze, M., Bruns, A., \& Neuberger, C. (2007). Preparing for an Age of Participatory News. Journalism Practice, 1(3), 322-338.

Domingo, D. (2008). Interactivity in the Daily Routines of Online Newsrooms: Dealing with an Uncomfortable Myth. Journal of Computer-Mediated Communication, 13(3), 680-704.

Domingo, D., Quandt, T., Heinonen, A., Paulussen, S., Singer, J. B., \& Vujnovic, M. (2008). Participatory Journalism Practices in the Media and Beyond: An International Comparative of Initiatives in Online Newspapers. Journalism Practice, 2(3), 326342.

Fröhlich, R., Quiring, O. \& Engesser, S. (2012). Between Idiosyncratic Self-Interests and Professional Standards: A Contribution to the Understanding of Participatory 
Journalism in Web 2.0. Result from a German Online Survey. Journalism, 13(8), 1039-1061.

Görke, A., \& Scholl, A. (2006). Niklas Luhmann's Theory of Social Systems and Journalism Research. Journalism Studies, 7(4), 644-655.

Heinonen, Ari (2011). The Journalist's Relationship with Users. New Dimensions to Conventional Roles. In Singer, J. B., Hermida, A., \& Domingo, D. (Ed.), Participatory Journalism. Guarding Open Gates at Online Newspapers (pp. 34-55). Chichester: Wiley-Blackwell.

Heinrich, A. (2011). Network Journalism: Journalistic Practices in Interactive Spheres. New York, London: Routledge Taylor \& Francis Group.

Hermida, A., \& Thurman, N. (2008). A Clash of Cultures: The Integration of UserGenerated content within professional journalistic frameworks at British newspaper websites. Journalism Practice, 2(3), 343-356.

Jönsson, A. M., \& Örnebring, H. (2011). User-Generated Content and the News: Empowerment of Citizens or Interactive Illusion? Journalism Practice, 5(2), 127144.

Karlsson, M. (2011). Flourishing But Restrained: The Evolution of Participatory Journalism in Swedish Online News, 2005-2009. Journalism Practice, 5(1), 68-84.

Lewis, S. C. (2012). The Tension Between Professional Control and Open Participation: Journalism and its Boundaries. Information, Communication \& Society, 15(6), 836866.

Loosen, W., \& Schmidt, J.-H. (2012). (Re-)Discovering the Audience: The Relationship Between Journalism and Audience in Networked Digital Media. Information, Communication \& Society, 15(6), 867-887.

Lüders, M. (2008). Conceptualizing Personal Media. New Media \& Society, 10(5), 683-702.

Mitchelstein, E., \& Boczkowski, P. J. (2009). Between Tradition and Change: A Review of Recent Research on Online News Production. Journalism, 10(5), 562-586.

Neuberger, C. (2009). Internet, Journalismus und Öffentlichkeit: Analyse des Medienumbruchs. In C. Neuberger, C. Nuernbergk, \& M. Rischke (Eds.), Journalismus im Internet: Profession, Partizipation, Technisierung (pp. 19-105). Wiesbaden: VS Verlag für Sozialwissenschaften.

Paulussen, S., \& Ugille, P. (2008). User Generated Content in the Newsroom: Professional and Organisational Constraints on Participatory Journalism. Westminster Papers in Communication and Culture, 5(2), 24-41.

Rebillard, F., \& Touboul, A. (2010). Promises Unfulfilled?: 'Journalism 2.0', User Participation and Editorial Policy on Newspaper Websites. Media, Culture \& Society, 32(2), 323-334.

Robinson, S. (2010). Traditionalists vs. Convergers: Textual Privilege, Boundary Work, and the Journalist-Audience Relationship in the Commenting Policies of Online News Sites. Convergence: The International Journal of Research into New Media Technologies, 16(1), 125-143.

Schmidt, J.-H. (2011). (Micro)blogs: Practices of Privacy Management. In S. Trepte, \& L. Reinecke (Eds.), Privacy Online. Perspectives on Privacy and Self-Disclosure in the Social Web (pp. 159-173). Berlin: Springer Science \& Business Media.

Scholl, A. (2004). Die Inklusion des Publikums. Theorien zur Analyse der Beziehungen von Journalismus und Publikum. In M. Löffelholz (Ed.), Theorien des Journalismus. Ein diskursives Handbuch (pp. 517-536). Wiesbaden: VS Verlag für Sozialwissenschaften.

Singer, J. B. (2010). Quality Control: Perceived Effects of User-Generated Content on Newsroom Norms, Values and Routines. Journalism Practice, 4(2), 127-142.

Singer, J. B., Hermida, A., Domingo, D., Heinonen, A., Paulussen, S., Quandt, T., Reich, Z., \& Vujnovic, M. (Eds.). (2011). Participatory Journalism: Guarding Open Gates at Online Newspapers. Chichester: Wiley-Blackwell.

Stichweh, R. (2005). Inklusion und Exklusion: Studien zur Gesellschaftstheorie. Bielefeld: transcript Verlag. 
van Dijck, J. (2009). Users Like You?: Theorizing Agency in User-Generated Content. Media, Culture \& Society, 31(1), 41-58.

Wardle, C., \& Williams, A. (2010). Beyond User-Generated Content: A Production Study Examining the Ways in Which UGC is Used at the BBC. Media, Culture \& Society, 32(5), 781-799.

Williams, A., Wardle, C., \& Wahl-Jorgensen, K. (2010). Have They Got News For Us?: Audience Revolution or Business as Usual at the BBC? Journalism Practice, 1-15.

Witschge, T. (2011). Changing Audiences, Changing Journalism? In P. Lee-Wright, A. Phillips, \& T. Witschge (Eds.), Changing Journalism (pp. 117-134). London: Routledge.

Zurstiege, G. (2006). Wishful Thinking: Questioning the Operative Fiction of Media Communities. In B. Hipfl, \& T. Hug (Eds.), Media Communities (pp. 65-73). Münster: Waxmann. 